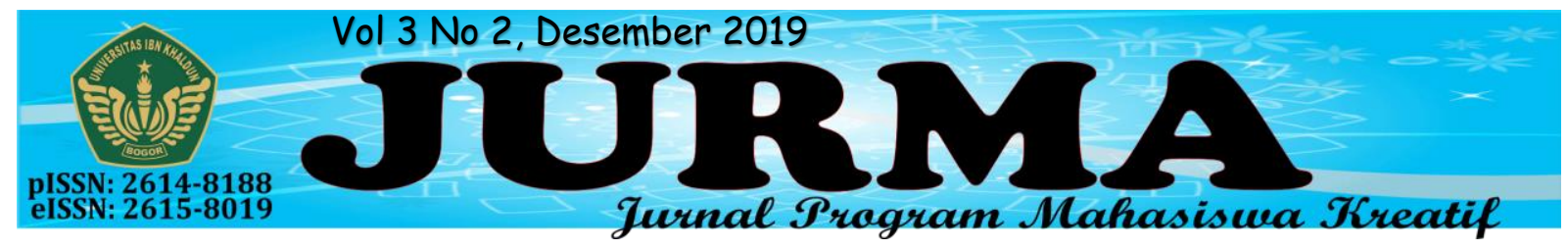

\title{
PENERAPAN PEMIKIRAN AL UMRAN IBNU KHALDUN UNTUK PEMBERDAYAAN MASYARAKAT
}

\author{
Intan \\ yuni03hijrah@gmail.com \\ Mahasiswa Fakultas Agama Islam Universitas Ibn Khaldun
}

\begin{abstract}
ABSTRAK
Perubahan zaman akan selalu menimbulkan perubahan tuntutan pada lapisan masyarakat. Hal tersebut akan merubah peran orang-orang yang hidup di dalam perubahan tersebut. Berangkat dari fenomena sosial yang ada saat ini, penulis melihat kondisi masyarakat yang rapuh dan memprihatinkan. Banyak penyimpangan-penyimpangan sosial yang terjadi di masyarakat. Maka akibat yang timbul adalah konflik dan perseteruan masyarakat. Efek ini mengakibatkan terganggunya rasa aman dan nyaman dalam masyarakat. Pada dasarnya suatu masyarakat adalah sebuah kumpulan manusia yang memiliki kepentingan bersama. Tujuan Penelitian Memahami dan menerapkan konsep Al Umran Ibnu Khaldun dan Memahami langkah-langah strategis untuk pemberdayaan masyarakat melalui konsep Al Umran.
\end{abstract}

Kata Kunci: Konsep Al Umran Ibnu Khaldun, Konflik dan Perseturuan Masyarakat, Pemberdayaan Masyarakat, .

\section{PENDAHULUAN}

Perubahan zaman akan selalu menimbulkan perubahan tuntutan pada lapisan masyarakat. Hal tersebut akan merubah peran orang-orang yang hidup di dalam perubahan tersebut. Dengan demikian setiap orang dituntut agar mengerti, memahami dan selanjutnya menyelaraskan kehidupannya dengan situasi, tuntutan serta irama kehidupan yang sedang berlangsung.

Berangkat dari fenomena sosial yang ada saat ini, penulis melihat kondisi masyarakat yang rapuh dan memprihatinkan. Banyak penyimpanganpenyimpangan sosial yang terjadi di masyarakat. Rasa kepedulian untuk hidup berdampingan bersama dengan saling menghormati dan mengakui perbedaan masing-masing, hampir menghilang.

Maka akibat yang timbul adalah konflik dan perseteruan masyarakat. Efek ini mengakibatkan terganggunya rasa aman dan nyaman dalam masyarakat. Bahkan yang lebih parah adanya perseteruan antar suku, antar ras hingga antar agama yang semakin tajam. Itu semua semakin memperburuk kondisi bangsa ini, yang tentunya akan merugikan citra di masyarakat dunia.

Memahami masyarakat haruslah memahami konsep manusia dalam arti sebenarnya. Terlebih bagi bangsa kita yang mempunyai keanekaragaman budaya, suku, bahasa, dan agama yang diikat oleh rasa kesatuan yang kita kenal dengan sebutan Bhineka Tunggal Ika. Masyrakat yang ideal dan berkualitas ialah masyarakat yang peduli terhadap kehidupannya sendiri, kehidupan 
sesamanya, serta lingkungan tempat hidupnya.

Pada dasarnya suatu masyarakat adalah sebuah kumpulan manusia yang memiliki kepentingan bersama. Kemampuan untuk meningkatkan kualitas masyarakat menuntut kejelasan konsep bagaimana sebuah kelompok atau organisasi masyarakat harus dan akan seperti apa dibangun dan membangunnya. Jadi langkah sementara adalah tentukan dan kembangkan konsep menjadi masyarakat yang ideal.

\section{Perumusan Masalah}

1. Bagaimana konsep Masyarakat saat ini?

2. Bagaimana penerapan konsep Al Umran Ibnu Khaldun?

3. Apa langkah-langkah strategis untuk pemberdayaan Masyarakat melalui konsep Pemikiran Al Umran Ibnu Khaldun?

\section{Tujuan Penelitian}

1. Untuk memahami Masyarakat saat ini

2. Memahami dan menerapkan konsep Al Umran Ibnu Khaldun

3. Memahami langkah-langah strategis untuk pemberdayaan masyarakat melalui konsep Al Umran

\section{Urgensi Penelitian}

Urgensi dari penelitian ini adalah dapat memahami dan berusaha menerapkan konsep pemikiran Al Umran Ibnu Khaldun untuk pemberdayaan masyarakat sehingga, dapat terbentuk masyarakat yang saling memahami, mengasihi, dan simpatik. Hal tersebut menjadi acuan untuk membangun Negara yang makmur dan sejahtera lewat konsep pemberdayaan masyarakat yang sudah saling diantaranya adalah penerapan taaruf, tafahum, dan tafakul.

\section{Manfaat Penelitian}

a. Bagi Masyarakat

1. Menciptakan suasana lingkungan yang harmonis dengan saling memahami, mengerti, dan saling membantu.

2. Terciptanya integritas antar individuindividu maupun kelompok.

3. Rasa simpatik dan empatik akan meningkatkan taraf kesejateraan dan kebahagiaan hidup dalam bermasyarakat.

b. Bagi Peneliti

Menjadi motivasi untuk senantiasa memanusiakan manusia dengan sebaik-baiknya sebagai makhluk ciptaan Tuhan yang Maha Esa.

\section{Luaran Penelitian}

Terjalinnya konsep ini dengan tumbuhnya rasa saling memiliki, memahami, dan mengasihi satu sama lain baik untuk dirinya sendiri sebagai manusia dan untuk orang lain yang berada dalam kelompok-kelompok sebagai sesama manusia. Tempat-tempat pemberdayaan masyarakat dan pertemuan masyarakat seperti majelis-majelis ilmu dapat selalu diminati untuk bertukar ide dan gagasan guna memajukan masyarakat, agama, dan bangsa secara gotong-royong dan beretika, beradab, dan berakhlakul karimah. 


\section{TINJAUAN PUSTAKA}

\section{Biografi Ibnu Khaldun}

Nama lengkap Ibnu Khaldun adalah Waliyuddîn Abu Zaid Abdurrahmân bin Muhammad Ibnu Khaldun al-Hadrami alIshbili.Beliau dilahirkan di Tunisia pada awal Ramadlan $732 \mathrm{H}$ atau tanggal $27 \mathrm{Mei}$ 13322 dan wafat di Kairo pada tanggal 17 Maret 1406. Keluarganya berasal dari Hadramant yang kemudian berimigrasi ke Seville (Spanyol) pada abad ke-8 setelah semenanjung itu dikuasai Arab Muslim.

Keluarga Ibnu Khaldun proUmayyah dan selama bertahuntahun menduduki posisi tinggi dalam politik di Spanyol sampai akhirnya hijrah ke Maroko. Setelah dari Maroko, mereka menetap di Tunisia dan di Negara ini mereka dihormati pihak istana dan diberi tanah milik dinasti Hafsiah. Sejak kecil Ibnu Khaldun terlibat dalam kegiatan intelektual di kota kelahirannya, di samping mengamati dari dekat kehidupan politik.

\section{Konsep Al Umran}

Memahami masyarakat haruslah memahami konsep manusia dalam arti sebenarnya. Terlebih bagi bangsa kita yang mempunyai keanekaragaman budaya, suku, bahasa, dan agama yang diikat oleh rasa kesatuan yang kita kenal dengan sebutan Bhineka Tunggal Ika. Masyrakat yang ideal dan berkualitas ialah masyarakat yang peduli terhadap kehidupannya sendiri, kehidupan sesamanya, serta lingkungan tempat hidupnya.

Pada dasarnya suatu masyarakat adalah sebuah kumpulan manusia yang memiliki kepentingan bersama. Kemampuan untuk meningkatkan kualitas masyarakat menuntut kejelasan konsep bagaimana sebuah kelompok atau organisasi masyarakat harus dan akan seperti apa dibangun dan membangunnya. Jadi langkah sementara adalah tentukan dan kembangkan konsep menjadi masyarakat yang ideal.

Secara etimologis pengembangan berarti membina dan meningkatkan kualitas. Dalam hal ini gagasan yang di fokuskan terhadap pemikiran Ibnu Khaldun memberikan kontribusi terhadap perkembangan masyarakat khususnya Islam yang masih relevan pada zaman sekarang. Sebagai perintis ilmu sosial, Ibnu Khaldun adalah orang pertama yang merumuskan hukum - hukum kemasyarakatan.

Ada beberapa konsep pengembangan masyarakat Islam yang dinukilkan Ibn Khaldun didalam karya tulisan bukunya, Muqaddimah yaitu:

1. Individu

Dalam pemikiran sosiologis, Ibnu Khaldun menjelaskan bahwa manusia itu diberikan kelebihan. Maka, kelebihan itu sejatinya dikembangkan bersamaan dengan semangat, inovasi, motivasi, dan dedikasi yang menggebu-gebu.

2. Ashabiyah

Atau yang bisa juga disebut kekeluargaan, merupakan sebuah kekuatan atas pertalian darah. Ada hubungan yang kental dari ikatan darah tersebut.

3. Masyarakat Ijtima Al-Insani

Dengan sikap yang saling membutuhkan tolong-menolong dan solidaritas maka terciptalah sistem sosial masyarakat Islam yang tergabung dalam masyarakat Ijtima Al-Insani.

4. Negara 
Negara dalam konteks ini adalah merupakan suatu wadah dan alat baik melalui pemimpin, konstitusi ataupun undang-undang untuk menciptakan tatanan masyarakat yang ideal sesuai ajaran Islam

5. Peradaban

Tujuan akhir dari pengembangan masyarakat islam adalah terwujudnya masyarakat madani.

Ibnu Khaldun menyatakan bahwa ilmu ini merupakan kumpulan dari segala ilmu pengetahuan, termasuk di antaranya ilmu sosiologi. Al-Umrân mempunyai makna luas, meliputi seluruh aspek aktifitas kemanusiaan, di antaranya frame geografi peradaban, perekonomian, sosial, politik, dan ilmu pengetahuan.

Maksud dari al-umrân dalam kerangka pemikiran Ibnu Khaldun adalah ilmu metodologi umum yang membahas tentang dasar-dasar peradaban, dan dengannya, tercapai puncak peradaban bumi. Secara natural, menurut Ibnu Khaldun, manusia membutuhkan interaksi dalam menumbuhkan peradaban, karena menurutnya manusia secara tabiat adalah makhluk sosial.

Oleh karena itu, manusia harus berkumpul, karena hal ini merupakan karakteristik kesosialannya. Hal seperti ini mengandung makna esensial dari sebuah peradaban. Karena pertemuan sangat urgen

\section{METODE PENELITIAN}

\section{Sumber Data}

Sumber data yang didapat dari penelitian ini adalah dari masyarakat kota Bogor dengan mengisi kuiseoner online dan offline yang disebar kepada masyarakat sehingga dapat memudahkan masyarakat untuk mengisinya bagi kehidupan manusia. Tanpa pertemuan, keberadaannya tidak sempurna.

Imam Hasan Al Banna menetapkan tiga pilar ikatan ukhuwah yaitu Taaruf, Tafahum, dan Takaful. Konsep ini juga yang harus di kembangkan dalam kehidupan bermasyarakat. Taaruf yang berarti saling mengenal atau mengetahui. Taaruf mengetahu secara jelas dan nyata terkait psikologis individunya dan atau kelompoknya di dalam masyarakat.

Seperti yang di firmankan Allah dalam QS Al Hujurat; 13 yang artinya "Wahai manusia sungguh kami telah menciptakan kamu dari seorang laki-laki dan seorang perempuan. Kemudian kami jadikan kamu berbangsa-bangsa dan bersuku-suku agar kamu saling mengenal. Sungguh yang paling mulia diantara kamu di sisi Allah ialah orang yang paling bertaqwa. Sungguh Allah Maha Mengetahui dan Maha Teliti."

Kemudian, ada Tafahum yang berarti saling memahami. Setiap manusia harus saling memahami agar timbul rasa saling pengertian, saling mengasihi, saling menyayangi, dan slaing mencintai. Tidak akan ada perselisishan dan pedebatan yang terjadi jika tafahum diterapkan di lingkungan masyarakat. Selanjutnya, ada Takaful yang berarti saling menanngung atau memikul beban. Beban yang di maksud disini adalah beban sesama manusia. Agar saling membantu dan meringankan.

\section{Teknik Pengumpulan Data}

Dalam memperoleh data-data yang diuji kebenarannya, maka perlu dilakukan proses pengumpulan data yang didalamnya terdiri dari informasi- informasi yang diterima oleh penyusun baik dalam lisan maupun tulisan. 
Dalam penelitian ini data yang dikumpulkan dengan cara penyebaran kuiseoner secara online dan juga offline. Dalam pembuatan pertanyaan dalam kuiseoner akan dibuat beberapa butiran soal yang digambarkan pada variabel- variabel penelitian. Variabel yang digunakan pada penelitian ini adalah variabel yang tidak dapat diukur secara langsung, yaitu: Variabel Independen (A) yaitu penggunaan gadget dan Variabel Dependen (M) yaitu minat literasi.

\section{BIAYA DAN JADWAL KEGIATAN}

Anggaran Biaya

\begin{tabular}{|c|l|l|}
\hline $\mathrm{N}$ & Jenis Pengeluaran & Biaya (Rp) \\
\hline 1 & Perlengkapan yang diperlukan & Rp. 9.000 .000 \\
\hline 2 & Bahan habis pakai & Rp. 2.000 .000 \\
\hline 3 & Perjalanan & Rp. 1.000 .000 \\
\hline 4 & lain-lain Jumlah & Rp. 500.000 \\
\hline \multicolumn{2}{|c|}{ Rp. 12.500.000 } \\
\hline
\end{tabular}

Jadwal Kegiatan

\begin{tabular}{|c|l|c|c|c|c|c|}
\hline \multirow{2}{*}{ No. Jenis Kegiatan } & \multicolumn{5}{|c|}{ Bulan } \\
\cline { 3 - 7 } & \multicolumn{1}{|c|}{$\begin{array}{l}\text { Meminta Izin ke Pemerintah Kota dan Warga } \\
\text { sekitar }\end{array}$} & & & & & \\
\hline 2 & Sosialisasi Konsep Al Umran Ibnu Khaldun & & & & & \\
\hline 3 & $\begin{array}{l}\text { Pembelian Al-Qur'an, Buku Muqaddimah dan buku } \\
\text { penunjang lainnya }\end{array}$ & & & & \\
\hline 4 & Peresmian konsep di majelis-majelis Ilmu & & & & & \\
\hline
\end{tabular}

\section{DAFTAR PUSTAKA}

Al Qur'annul Karim

Ibnu Khaldun, Muqadimah, Terjemah, (Jakarta: Pustaka Al Kautsar 2011 M
Abdullah. 2003. Tafsir Ibn Katsir. Bogor: Pustaka Imam As Syafii

Shaleh Ahmad Asy-Syaami, Berakhlak dan Beradab Mulia (Jakarta: Gema Insani) 2005 